\title{
Determination of Cyanide Content in Three Sweet Cassava Cultivars in Three Local Government Areas of Benue State, Nigeria
}

\author{
Simon Terver Ubwa, Monday Abel Otache, Gillian Ogbene Igbum, Tseaa Shambe* \\ Department of Chemistry, Benue State University, Makurdi, Nigeria \\ Email: "tshambe@bsum.edu.ng
}

Received 5 August 2015; accepted 4 September 2015; published 7 September 2015

Copyright $@ 2015$ by authors and Scientific Research Publishing Inc.

This work is licensed under the Creative Commons Attribution International License (CC BY).

http://creativecommons.org/licenses/by/4.0/

(c) (i) Open Access

\section{Abstract}

The cyanide content of the parenchyma (pulp) of three sweet cassava cultivars: Alhaji (Tropical Manihot Selection; TMS 98/0581), Ochengbila (Tropical Manihot Selection; TMS 98/0505), and Onono (Tropical Manihot Selection; TMS 98/0524) from three local government areas of Benue State were studied. Their contents were: TMS 98/0581 (41.46 - 53.40) $\mathrm{mg} / \mathrm{kg}$, TMS 98/0505 $(45.12-58.93) \mathrm{mg} / \mathrm{kg}$ and TMS $98 / 0524(46.38-58.08) \mathrm{mg} / \mathrm{kg}$ for all the local government areas. For the peels, it ranged from $(63.41-108.96) \mathrm{mg} / \mathrm{kg}$ for all cultivars. The cyanide content of the cultivars varies from one local government to another and also from one farm to another. No appreciable loss of cyanide was observed after four days of storage. The cyanide content of boiled and roasted cassava parenchyma was $(5.26-7.85) \mathrm{mg} / \mathrm{kg}$ and $(9.73-10.55) \mathrm{mg} / \mathrm{kg}$ respectively for all the cultivars. Air dried parenchyma at $\left(26^{\circ} \mathrm{C}-32^{\circ} \mathrm{C}\right.$ for one week and oven dried parenchyma at $60^{\circ} \mathrm{C}$ for four hours ranged from $(16.05-18.83) \mathrm{mg} / \mathrm{kg}$ and $(21.82-24.04) \mathrm{mg} / \mathrm{kg}$ respectively for all cultivars.

\section{Keywords}

Cassava, Cultivar, Cyanide Content, Place of Growth, Roasted, Boiled

\section{Introduction}

There are about 2600 plant species that produce cyanogenic glycosides [1]-[4]. When cassava leaves or tubers are detached from the plant, cyanogenic glycosides are hydrolysed by enzymes, to alpha-hydroxynitrile and sugar or a saccharide. Alpha-hydroxynitrile formed undergoes intramolecular reaction to give hydrogen cyanide,

"Corresponding author.

How to cite this paper: Ubwa, S.T., Otache, M.A., Igbum, G.O. and Shambe, T. (2015) Determination of Cyanide Content in Three Sweet Cassava Cultivars in Three Local Government Areas of Benue State, Nigeria. Food and Nutrition Sciences, 6, 1078-1085. http://dx.doi.org/10.4236/fns.2015.612112 
highly poisonous, and anal or ketone. Oral lethal dosage of hydrogen cyanide for adults is [0.58 - 3.5] mg/kg of body weight [5]. Cassava containing $(50-60) \mathrm{mg} / \mathrm{kg}$ is therefore to be pre-treated to reduce cyanide to acceptable level.

Manihot esculenta Crantz (cassava) is a perennial crop native to tropical America [6]. Cassava is a woody shrub which belongs to the genus of the natural order or family of Euphorbiaceae [7] [8]. The Manihot genus is reported to have about 100 species, among which the only commercially cultivated one is Manihot esculenta Crantz [9]. The carbohydrate rich storage tuber serves as an important energy source and staple food for mankind and animals mostly in Africa and other parts of the world [10]. The cassava plant is among the crops that have high amount of carbohydrates [9]. The plant is identified by the nature of its leaves, starchy tuberous root and the color of its parenchyma [9]. It has high rate of post harvest losses when not properly handled during harvesting [11]. The three distinct tissues of the matured cassava storage tuber include the periderm, cortex and pulp [12] [13]. Cassava cultivars have advantage over other tuber crops due to its ability to survive on poor soils and its resistance to drought [14] [15]. The leaves which are rich in proteins, vitamins and minerals also contain high level of cyanide and as a result, are not preferred for human consumption [16]. Cassava cultivars can be classified into high cyanide (bitter) and low cyanide (sweet) [10] [17] [18]. Production of cyanide by various cultivars is affected by soil, weather and other geographical conditions [19], same cultivars may produce high cyanide in one location and significantly lower value in another [20]. Consequently, it is necessary to assay for cyanide content of cassava tubers irrespective of the cultivars before used for human consumption.

The recommended World health Organization (WHO) maximum acceptable level of cyanide in foods meant for human consumption is below $10 \mathrm{mg} / \mathrm{kg}$ [21] [22]. Cassava tubers of all cultivars contain cyanide above this recommended level [23]. Cyanide is usually removed from tubers by fermentation, boiling, steaming, drying, roasting and other methods [24] [25]. In this study, efforts are made to effect the removal of cyanide from sweet cassava cultivars using heat (boiling and roasting) which are available methods to local consumers. The study areas are Apa, Otukpo and Ushongo local government areas of Benue State, Nigeria, West Africa.

\section{Materials and Methods}

\subsection{Materials}

Digital Environmental Thermometer (VC-500, Zhijian, China), Ninhydrin (Reidel-de Hean, AG D-3016), Potassium Cyanide (8847, Pharmacos LTD, southend-on-sea, essex England), NaCl (UN 1823, J.T Baker, Deventer, Holland), $\mathrm{NaHCO}_{3}$ and $\mathrm{Na}_{2} \mathrm{CO}_{3}$ (BH-15 LTD, BDH Laboratory, England). All reagents used in this study are analytical grade.

\subsection{Sampling Collection}

Tubers of the three cassava varieties were collected from Otukpo, Apa and Ushongo local government areas of Benue State. Samples were collected in triplicate from three different farms in each of the districts studied and the temperature at each collection point was recorded. The samples were; Alhaji (TMS 98/0581), Ochengbila (TMS 98/0505), and Onono (TMS 98/0524). Their trade identities were authenticated at the Benue State Agricultural Research and Development Agency (BNARDA), Makurdi, Benue State.

\subsection{Treatment of Samples}

The cassava tubers were properly washed to remove soil. The outer dark brown scale covering (periderm) was removed. The Cassava samples were cleaned using distilled water, $10.0 \mathrm{~g}$ of the weighed samples were roasted, while the other portion (10.0 g) was boiled in distilled water, using stainless steel materials, for 15, 20 and 35 minutes respectively. The remaining portion was ground and homogenized in a mortar with a pestle. The homogenized sample was divided into two portions; one portion air dried and the other oven dried. Unpeeled cassava samples were analyzed at intervals of Day 1 (day of harvest), Day 2, Day 3 and Day 4 of storage at ambient temperature.

\subsection{Hydrogen Cyanide Determination in Cassava Tubers}

The cyanide concentration in cassava parenchyma was determined using ninhydrin based spectrometer of trace cyanide at $485 \mathrm{~nm}$ maximum wavelength [26]. A calibration graph was first constructed using standard solutions 
of $\mathrm{CN}^{-}$at concentrations of $0.02,0.04,0.08,0.1$ and $0.2 \mu \mathrm{g} / \mathrm{mL}$ (which is within the linear range) and was prepared by adding appropriate volumes of cyanide solutions at concentration of $20 \mu \mathrm{g} \mathrm{CN}-/ \mathrm{mL}$ to $1 \mathrm{~mL}$ of $2 \%$ $\mathrm{Na}_{2} \mathrm{CO}_{3}$. Ninhydrin solution $(0.5 \mathrm{~mL})$ containing $5 \mathrm{mg} / \mathrm{mL}$ in $2 \% \mathrm{NaOH}$ was added to each standard cyanide solution. The mixture was homogenized and incubated for 15 minutes for color development. Similarly, the blank was prepared in the same way as above, except that instead of $1 \mathrm{~mL} 2 \% \mathrm{Na}_{2} \mathrm{CO}_{3}$ containing $\mathrm{CN}^{-}, 1 \mathrm{~mL}$ of $2 \% \mathrm{Na}_{2} \mathrm{CO}_{3}$ without $\mathrm{CN}^{-}$was added. UV-Visible absorption of the reaction product (Cyanide-ninhydrin adduct) of the different concentrations of cyanide was measured using UV/Vis Spectrophotometer (SURGISPEC SM 735, Surgical Medical, England) at $485 \mathrm{~nm}$. Total cyanide in the samples was determined by adding $0.1 \mathrm{~g}$ of the ground sample in a standard volumetric flask $(5 \mathrm{~mL})$ and made up to mark with $0.1 \% \mathrm{NaHCO}_{3}$. The samples were sonicated for 20 minutes in a water bath and the mixture centrifuged at 10,000 rpm for 10 minutes. The supernatant was pipetted with automatic pipette, two aliquots ( $2 \mathrm{~mL}$ each) and added to $0.5 \mathrm{~mL}$ ninhydrin in $\mathrm{NaOH}$, allowed for fifteen minutes for color development and absorbance measured at $485 \mathrm{~nm}$.

\subsection{Statistical Analysis}

Means of the samples were compared using analysis of variance (ANOVA) and the level of significant difference determined at $\mathrm{p}<0.05$. This analysis was carried out with an SPSS program (version 21) (IBM).

\section{Results and Discussion}

\subsection{Effect of Harvesting Time on Cyanide Content}

The results of cyanide concentration in the studied areas are presented in Tables 1-8. From the results, it can be seen that cyanide content for the same cultivars are different from one local government to the other, it can also be seen that even in the same local government, different locations gave different values for same cultivars. These results are in line with earlier observations [14] [20].

The concentration of cyanide in cassava parenchyma at different temperatures from Otukpo Local Government (Tables 1-3) reveals that Chito recorded an average cyanide concentration ranging from (45.43 \pm 0.00 at $28^{\circ} \mathrm{C}$ to $58.08 \pm 0.01$ at $\left.26^{\circ} \mathrm{C}\right) \mathrm{mg} / \mathrm{kg}$ for TMS $98 / 0581$ and TMS $98 / 0524$,Otada recorded $\left(46.27 \pm 0.06\right.$ at $29^{\circ} \mathrm{C}$ to $58.93 \pm 0.05$ at $\left.28^{\circ} \mathrm{C}\right) \mathrm{mg} / \mathrm{kg}$ for TMS $98 / 0581$ and TMS 98/0505, while Eupi recorded values ranging between $\left(44.38 \pm 0.04\right.$ at $30^{\circ} \mathrm{C}$ to $50.23 \pm 0.04$ at $\left.27^{\circ} \mathrm{C}\right) \mathrm{mg} / \mathrm{kg}$ for TMS $98 / 0581$ and TMS 98/0524 respectively.

In Apa local government (Tables 4-6), Ugbokpo recorded values ranging from (43.89 \pm 0.03 at $35^{\circ} \mathrm{C}$ to

Table 1. Cyanide concentration of samples from Otukpo (Chito) (mg/kg).

\begin{tabular}{|c|c|c|c|c|c|}
\hline \multirow{2}{*}{ Sample } & & \multicolumn{2}{|c|}{ Temperatures } & & \\
\hline & & & Tubers & \multicolumn{2}{|c|}{ Peels } \\
\hline \multicolumn{2}{|l|}{$\mathrm{n}$} & $26^{\circ} \mathrm{C}$ & $30^{\circ} \mathrm{C}$ & \multicolumn{2}{|c|}{$28^{\circ} \mathrm{C}$} \\
\hline TMS 98/0581 & 3 & $51.74^{\complement} \pm 0.02$ & $48.37^{\mathrm{c}} \pm 0.03$ & $45.43^{c} \pm 0.00$ & $94.79^{c} \pm 0.01$ \\
\hline TMS 98/0505 & 3 & $56.77^{\mathrm{b}} \pm 0.01$ & $52.34^{\mathrm{b}} \pm 0.01$ & $53.23^{\mathrm{b}} \pm 0.00$ & $103.37^{\mathrm{b}} \pm 0.00$ \\
\hline TMS 98/0524 & 3 & $58.08^{\mathrm{a}} \pm 0.01$ & $55.96^{\mathrm{a}} \pm 0.02$ & $55.53^{a} \pm 0.07$ & $108.96^{\mathrm{a}} \pm 0.01$ \\
\hline
\end{tabular}

$\mathrm{n}=$ number of samples. $\mathrm{a}, \mathrm{b}$ and c shows the variance of the three cultivars measured at different sites, as determined by ANOVA at $\mathrm{p}<0.05$.

Table 2. Cyanide concentration of samples from Otukpo (Otada) (mg/kg).

\begin{tabular}{|c|c|c|c|c|c|}
\hline \multirow{2}{*}{\multicolumn{2}{|c|}{ Sample }} & \multicolumn{2}{|c|}{ Temperatures } & & \\
\hline & & \multicolumn{2}{|r|}{ Tubers } & \multicolumn{2}{|c|}{ Peels } \\
\hline & $\mathrm{n}$ & $28^{\circ} \mathrm{C}$ & $34^{\circ} \mathrm{C}$ & \multicolumn{2}{|c|}{$29^{\circ} \mathrm{C}$} \\
\hline TMS 98/0581s & 3 & $48.59^{c} \pm 0.03$ & $47.33^{c} \pm 0.05$ & $46.27^{\mathrm{c}} \pm 0.06$ & $89.34^{\mathrm{C}} \pm 0.01$ \\
\hline TMS 98/0505 & 3 & $58.93^{\mathrm{a}} \pm 0.05$ & $48.87^{\mathrm{b}} \pm 0.06$ & $49.07^{\mathrm{b}} \pm 0.07$ & $99.33^{\mathrm{b}} \pm 0.02$ \\
\hline TMS 98/0524 & 3 & $56.59^{b} \pm 0.05$ & $54.68^{\mathrm{a}} \pm 0.03$ & $54.68^{\mathrm{a}} \pm 0.03$ & $105.73^{\mathrm{a}} \pm 0.01$ \\
\hline
\end{tabular}

a, b and c shows the variance of the three cultivars measured at different sites, as determined by ANOVA at $\mathrm{p}<0.05$. 
Table 3. Cyanide concentration of samples from Otukpo (Eupi) (mg/kg).

\begin{tabular}{cccccc}
\hline & & \multicolumn{3}{c}{ Temperatures } & \\
\cline { 3 - 6 } Sample & & & Tubers & Peels \\
\hline & $\mathrm{n}$ & $27^{\circ} \mathrm{C}$ & $31^{\circ} \mathrm{C}$ & $29^{\circ} \mathrm{C}$ \\
\hline TMS 98/0581 & 3 & $45.64^{\mathrm{c}} \pm 0.04$ & $44.38^{\mathrm{c}} \pm 0.04$ & $45.43^{\mathrm{b}} \pm 0.03$ & $94.36^{\mathrm{c}} \pm 0.04$ \\
TMS 98/0505 & 3 & $46.16^{\mathrm{b}} \pm 0.04$ & $45.12^{\mathrm{b}} \pm 0.04$ & $45.12^{\mathrm{c}} \pm 0.03$ & $94.19^{\mathrm{b}} \pm 0.03$ \\
TMS 98/0524 & 3 & $50.23^{\mathrm{a}} \pm 0.04$ & $48.11^{\mathrm{a}} \pm 0.04$ & $48.00^{\mathrm{a}} \pm 0.03$ & $101.78^{\mathrm{a}} \pm 0.02$ \\
\hline
\end{tabular}

a, $b$ and $\mathrm{c}$ shows the variance of the three cultivars measured at different sites, as determined by ANOVA at $\mathrm{p}<0.05$.

Table 4. Cyanide concentration of cassava samples from Apa (Ugbokpo) (mg/kg).

\begin{tabular}{|c|c|c|c|c|c|}
\hline \multirow{3}{*}{ Sample } & \multicolumn{5}{|c|}{ Temperature } \\
\hline & & \multicolumn{3}{|c|}{ Tubers } & \multirow[t]{2}{*}{ Peels } \\
\hline & $\mathrm{n}$ & $27^{\circ} \mathrm{C}$ & $29^{\circ} \mathrm{C}$ & $35^{\circ} \mathrm{C}$ & \\
\hline TMS98/0581 & 3 & $45.75^{c} \pm 0.03$ & $44.92^{\mathrm{c}} \pm 0.03$ & $43.89^{c} \pm 0.03$ & $87.81^{\mathrm{C}} \pm 0.08$ \\
\hline TMS 98/05053 & 3 & $50.09^{\mathrm{b}} \pm 0.04$ & $49.65^{b} \pm 0.05$ & $49.65^{b} \pm 0.03$ & $96.76^{\mathrm{b}} \pm 0.01$ \\
\hline TMS 98/0524 & 3 & $55.06^{\mathrm{a}} \pm 0.03$ & $53.19^{\mathrm{a}} \pm 0.04$ & $54.24^{\mathrm{a}} \pm 0.03$ & $98.29^{\mathrm{a}} \pm 0.05$ \\
\hline
\end{tabular}

a, $b$ and c shows the variance of the three cultivars measured at different sites, as determined by ANOVA at $\mathrm{p}<0.05$.

Table 5. Cyanide concentration of cassava samples from Apa (Amuke) (mg/kg).

\begin{tabular}{|c|c|c|c|c|c|}
\hline \multirow{3}{*}{ Sample } & \multicolumn{5}{|c|}{ Temperature } \\
\hline & \multicolumn{4}{|c|}{ Tubers } & \multirow[t]{2}{*}{ Peels } \\
\hline & $\mathrm{n}$ & $27^{\circ} \mathrm{C}$ & $28^{\circ} \mathrm{C}$ & $34^{\circ} \mathrm{C}$ & \\
\hline TMS98/0581 & 3 & $53.40^{a} \pm 0.06$ & $45.13^{c} \pm 0.00$ & $44.92^{\mathrm{C}} \pm 0.03$ & $86.30^{c} \pm 0.00$ \\
\hline TMS 98/05053 & 3 & $50.46^{\mathrm{c}} \pm 0.04$ & $47.59^{\mathrm{b}} \pm 0.03$ & $48.41^{b} \pm 0.03$ & $97.40^{\mathrm{b}} \pm 0.01$ \\
\hline TMS 98/0524 & 3 & $52.98^{\mathrm{b}} \pm 0.02$ & $50.70^{\mathrm{a}} \pm 0.04$ & $51.51^{a} \pm 0.04$ & $105.36^{\mathrm{a}} \pm 0.00$ \\
\hline
\end{tabular}

a, b and c shows the variance of the three cultivars measured at different sites, as determined by ANOVA at p $<0.05$.

Table 6. Cyanide concentration of cassava samples from Apa (Iga-Okpaya) (mg/kg).

\begin{tabular}{|c|c|c|c|c|c|}
\hline \multirow{3}{*}{ Sample } & \multicolumn{5}{|c|}{ Temperatures } \\
\hline & \multicolumn{4}{|c|}{ Tubers } & \multirow[t]{2}{*}{ Peels } \\
\hline & $\mathrm{n}$ & $26^{\circ} \mathrm{C}$ & $28^{\circ} \mathrm{C}$ & $30^{\circ} \mathrm{C}$ & \\
\hline TMS 98/0581 & 3 & $45.17^{\mathrm{C}} \pm 0.01$ & $44.13^{\mathrm{C}} \pm 0.01$ & $43.92^{c} \pm 0.01$ & $66.63^{c} \pm 0.01$ \\
\hline TMS 98/0505 & 3 & $47.06^{\mathrm{b}} \pm 0.01$ & $46.02^{b} \pm 0.00$ & $45.39^{b} \pm 0.00$ & $82.30^{b} \pm 0.04$ \\
\hline TMS 98/0524 & 3 & $49.32^{\mathrm{a}} \pm 0.01$ & $48.89^{\mathrm{a}} \pm 0.00$ & $48.27^{\mathrm{a}} \pm 0.00$ & $86.48^{\mathrm{a}} \pm 0.02$ \\
\hline
\end{tabular}

a, b and c shows the variance of the three cultivars measured at different sites, as determined by ANOVA at p $<0.05$.

Table 7. Cyanide concentration of cassava sample from Ushongo (Lobi-Kartyo).

\begin{tabular}{|c|c|c|c|c|c|}
\hline \multirow[t]{3}{*}{ Sample } & \multicolumn{5}{|c|}{ Temperatures } \\
\hline & \multicolumn{4}{|c|}{ Tubers } & \multirow[t]{2}{*}{ Peels } \\
\hline & $\mathrm{n}$ & $28^{\circ} \mathrm{C}$ & $36^{\circ} \mathrm{C}$ & $29^{\circ} \mathrm{C}$ & \\
\hline TMS 98/0581 & 3 & $44.30^{c} \pm 0.00$ & $46.78^{c} \pm 0.03$ & $41.46^{\mathrm{c}} \pm 0.03$ & $86.95^{\mathrm{C}} \pm 0.01$ \\
\hline TMS 98/0505 & 3 & $46.55^{b} \pm 0.00$ & $45.32^{\mathrm{b}} \pm 0.00$ & $44.91^{\mathrm{b}} \pm 0.01$ & $95.69^{\mathrm{b}} \pm 0.03$ \\
\hline TMS98/0524 & 3 & $48.83^{\mathrm{a}} \pm 0.00$ & $47.79^{\mathrm{a}} \pm 0.00$ & $47.58^{\mathrm{a}} \pm 0.01$ & $100.42^{\mathrm{a}} \pm 0.02$ \\
\hline
\end{tabular}

a, b and c shows the variance of the three cultivars measured at different sites, as determined by ANOVA at $\mathrm{p}<0.05$. 
Table 8. Cyanide concentration of cassava sample from Ushongo (Ber-Agbum).

\begin{tabular}{cccccc}
\hline Sample & \multicolumn{5}{c}{ Temperatures } \\
& \multicolumn{5}{c}{ Tubers } \\
\cline { 2 - 6 } & $\mathrm{n}$ & $28^{\circ} \mathrm{C}$ & $31^{\circ} \mathrm{C}$ & $29^{\circ} \mathrm{C}$ & Peels \\
\hline TMS 98/0581 & 3 & $47.66^{\mathrm{c}} \pm 0.01$ & $44.13^{\mathrm{c}} \pm 0.00$ & $45.38^{\mathrm{c}} \pm 0.00$ & $63.41^{\mathrm{c}} \pm 0.02$ \\
TMS 98/0505 & 3 & $50.78^{\mathrm{b}} \pm 0.00$ & $50.78^{\mathrm{a}} \pm 0.00$ & $50.16^{\mathrm{a}} \pm 0.00$ & $73.92^{\mathrm{b}} \pm 0.01$ \\
TMS98/0524 & 3 & $51.62^{\mathrm{a}} \pm 0.04$ & $47.01^{\mathrm{b}} \pm 0.00$ & $46.38^{\mathrm{b}} \pm 0.00$ & $84.31^{\mathrm{a}} \pm 0.01$ \\
\hline
\end{tabular}

a, b and c shows the variance of the three cultivars measured at different sites, as determined by ANOVA at $\mathrm{p}<0.05$.

$55.06 \pm 0.03$ at $27^{\circ} \mathrm{C}$, $) \mathrm{mg} / \mathrm{kg}$ for TMS 98/0581 and TMS 98/0524, Amuke recorded $\left(44.92 \pm 0.03\right.$ at $34^{\circ} \mathrm{C}$ to $53.40 \pm 0.03$ at $\left.27^{\circ} \mathrm{C}\right) \mathrm{mg} / \mathrm{kg}$ for TMS 98/0581, while Iga-Okpaya recorded $\left(43.92 \pm 0.01\right.$ at $28^{\circ} \mathrm{C}$ to $49.32 \pm$ 0.01 at $26^{\circ} \mathrm{C}$ ) $\mathrm{mg} / \mathrm{kg}$ for TMS 98/0581 and TMS 98/0524 respectively.

In Ushongo local government (Table 7 and Table 8), Lobi Kartyo showed an average cyanide concentration ranging from $\left(41.46 \pm 0.03\right.$ at $29^{\circ} \mathrm{C}$ to $48.83 \pm 0.00$ at $\left.28^{\circ} \mathrm{C}\right) \mathrm{mg} / \mathrm{kg}$, while Ber-Agbum recorded $(44.13 \pm 0.00$ at $31^{\circ} \mathrm{C}$ to $51.62 \pm 0.04$ at $28^{\circ} \mathrm{C}$ ) $\mathrm{mg} / \mathrm{kg}$ for TMS 98/0581 and TMS 98/0524 respectively.

The results show that the cyanide content is within the range of sweet cassava cultivars [14] [27]. This is in excess of the maximum acceptable limit recommended by WHO [21]. TMS 98/0524 recorded the highest values (46.38 - 58.08) $\mathrm{mg} / \mathrm{kg}$ in all the local government areas with only an exception in Otada (Otukpo) where TMS $98 / 0505$ had the highest value (58.93) $\mathrm{mg} / \mathrm{kg}$. For this reason, the practices of eating it raw should be discouraged. The sample collected in the morning contained more HCN than that collected in the afternoon and evening for all cultivars, but no clear trend was observed for those collected in the afternoon and evening [28]. It is most probable that the unstable alpha hydroxynitrile undergoes intramolecular reaction at temperatures above $30^{\circ} \mathrm{C}$ to produce a ketone and HCN which will invariably react with amino acid containing sulphur to give thiocyanate [29]-[31]. This is possible if the available sulphur containing amino acids are more than the sugars available in the afternoon and evening [31] [32]. The cyanide content of the peels ranges from (63.41 - 108.96) $\mathrm{mg} / \mathrm{kg}$ in all the cultivars in all the local government areas.

\subsection{Effect of Days of Storage on Cyanide Content}

The result of effects of days of storage is presented in Table 9. Unpeeled tubers left for four days did not show appreciable change in the cyanide content (Table 9). The temperatures for keeping this ranged from $26^{\circ} \mathrm{C}-29^{\circ} \mathrm{C}$. This shows that hydrolysis of cyanogenic glycosides to release hydrogen cyanide was not rapid since HCN vaporizes at $26^{\circ} \mathrm{C}$ [33].

\subsection{Effect of Boiling Time and Roasting on Cyanide Concentration of Peeled Cassava Tuber (mg/kg)}

Figure 1 shows that cassava parenchyma boiled for 15 and 20 minutes ranges from (25.24 to 30.53) mg/kg and (18.30 to 21.19) $\mathrm{mg} / \mathrm{kg}$ respectively for all cultivars and remains high above the accepted limit of $10 \mathrm{mg} / \mathrm{kg}$ set by WHO. Further extension of boiling time to 35 minutes, reduced the level of cyanide in all the cultivars below the accepted level for human consumption (5.26 to 7.85) $\mathrm{mg} / \mathrm{kg}$. These values can further be reduced when the cassava is blended with boiled yam and/or sweet potatoes for making composite pounded yam as it is normally done by local consumers in Benue State. Reduction of cyanide content in cassava tubers by boiling has earlier been reported [14] [34]-[36].

The cyanide content of the parenchyma after roasting ranges between $(9.73-10.55) \mathrm{mg} / \mathrm{kg}$ in all the cultivars (Table 10). This is marginal within the acceptable range for all the cultivars for human consumption [21]. Hence eating of roasted cassava should be discouraged as the cultivars may contain cyanide level above the safe limit. These results show that roasting significantly reduced the total cyanide content in fresh root, but not as effective as boiling for 35 minutes.

\subsection{Effect of Drying on Cyanide Content}

Parenchyma air dried for 1 week $\left(26^{\circ} \mathrm{C}-32^{\circ} \mathrm{C}\right)$ and oven dried $\left(60^{\circ} \mathrm{C}\right)$ for 4 hours contained $(16.05-18.83)$ 


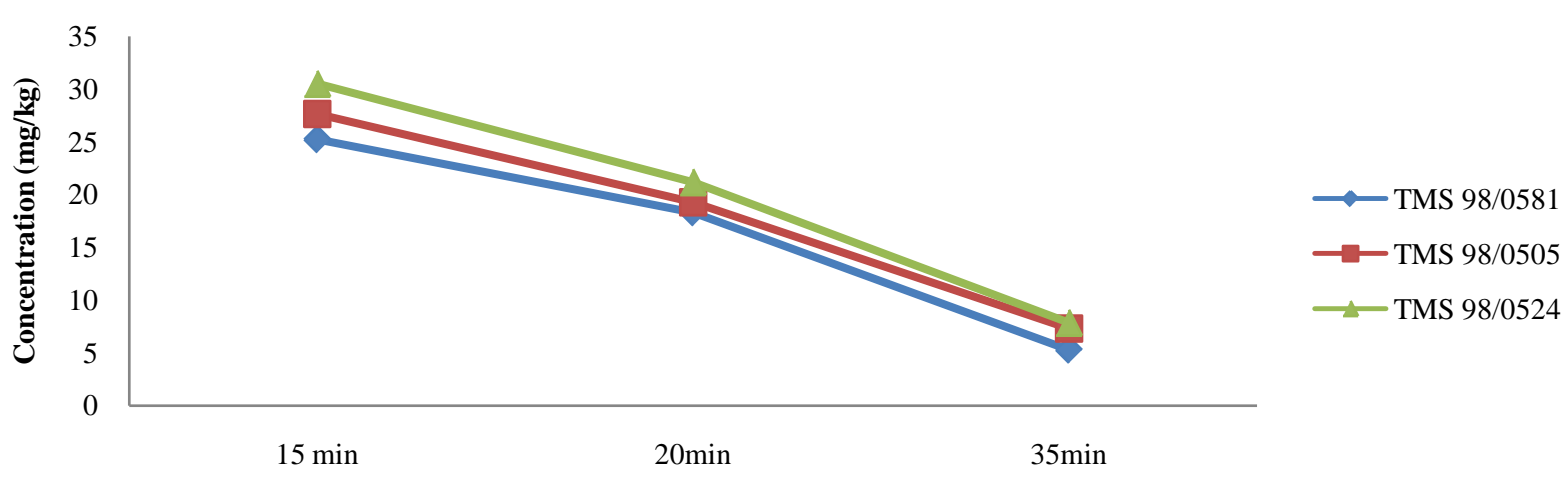

Figure 1. Effect of boiling time on the concentration of cyanide.

Table 9. Effect of days of storage on cyanide concentration of unpeeled cassava tubers (mg/kg).

\begin{tabular}{cccccc}
\hline Sample & $\mathrm{n}$ & 1 & 2 & 3 & 4 \\
\hline TMS 98/0581 & 3 & $42.91^{\mathrm{c}} \pm 0.01$ & $41.23^{\mathrm{c}} \pm 0.00$ & $40.80^{\mathrm{c}} \pm 0.00$ & $40.60^{\mathrm{c}} \pm 0.00$ \\
TMS 98/0505 & 3 & $51.15^{\mathrm{b}} \pm 0.01$ & $47.41^{\mathrm{b}} \pm 0.00$ & $45.95^{\mathrm{b}} \pm 0.00$ & $45.54^{\mathrm{b}} \pm 0.00$ \\
TMS 98/0524 & 3 & $55.32^{\mathrm{a}} \pm 0.01$ & $54.47^{\mathrm{a}} \pm 0.00$ & $51.91^{\mathrm{a}} \pm 0.00$ & $51.92^{\mathrm{a}} \pm 0.00$ \\
\hline
\end{tabular}

a, b and c shows the variance of the three cultivars measured at different sites, as determined by ANOVA at p $<0.05$.

Table 10. Effect of boiling time and roasting on cyanide concentration (mg/kg).

\begin{tabular}{|c|c|c|c|c|c|}
\hline \multirow{2}{*}{ Sample } & \multicolumn{3}{|c|}{ Boiling time } & \multicolumn{2}{|c|}{ Roasting } \\
\hline & $\mathrm{n}$ & $15 \min$ & $20 \mathrm{~min}$ & $35 \mathrm{~min}$ & $35 \mathrm{~min}$ \\
\hline TMS 98/0581 & 3 & $25.24^{\mathrm{c}} \pm 0.01$ & $18.30^{c} \pm 0.00$ & $5.26^{\mathrm{c}} \pm 0.00$ & $10.23^{\mathrm{b}} \pm 0.01$ \\
\hline TMS 98/0505 & 3 & $27.65^{b} \pm 0.01$ & $19.29^{b} \pm 0.00$ & $7.31^{b} \pm 0.00$ & $9.73^{\mathrm{c}} \pm 0.04$ \\
\hline TMS98/0524 & 3 & $30.53^{\mathrm{a}} \pm 0.00$ & $21.19^{\mathrm{a}} \pm 0.00$ & $7.85^{\mathrm{a}} \pm 0.00$ & $10.55^{\mathrm{a}} \pm 0.00$ \\
\hline
\end{tabular}

a, b and c shows the variance of the three cultivars measured at different sites, as determined by ANOVA at $\mathrm{p}<0.05$.

Table 11. Effect of drying on cyanide concentration $(\mathrm{mg} / \mathrm{kg})$.

\begin{tabular}{ccc}
\hline Sample & Oven dried (4 hours) & Air dried (1 week) \\
TMS 98/0581 & $21.85^{\mathrm{b}} \pm 0.00$ & $16.58^{\mathrm{b}} \pm 0.00$ \\
TMS 98/0505 & $21.82^{\mathrm{b}} \pm 0.00$ & $16.05^{\mathrm{c}} \pm 0.00$ \\
TMS 98/0524 & $24.04^{\mathrm{a}} \pm 0.00$ & $18.83^{\mathrm{a}} \pm 0.01$ \\
\hline
\end{tabular}

Results are the average of three determination expressed on dry weight basis and standard deviation. In the same column, values followed by a common letter are not significantly different at $\mathrm{p}<0.05$.

$\mathrm{mg} / \mathrm{kg}$ and (21.82 - 24.04) mg/kg of cyanide respectively for all cultivars (Table 11). These values are above the acceptable values by WHO and consequently not suitable for human consumption [5] [21]. The high concentration of cyanide after oven drying is in agreement with the observation that, the rapid temperature increase during oven drying could have deactivated the enzyme that is responsible for hydrolysis of cyanogenic glycoside [37]. It is therefore necessary to blend cassava tubers with yam or grains e.g. millet, guinea corn and maize to dilute the cyanide content to acceptable level.

\section{Conclusion}

The cyanide content of cassava cultivars studied ranges from $(44.46-56.78) \mathrm{mg} / \mathrm{kg}$. This is above acceptable limits provided by WHO for human consumption and should not be eaten raw even though it is sweet. The cyanide content changes with change in geographical location, hence there is need to continuously determine the cyanide in cassava before eating. Heat treatment reduces the cyanide content between (5.67 - 24.04) mg/kg. 
Heating by boiling is the most effective means of depleting cyanide content. Therefore, the present study highlights the importance of boiling cassava tubers for at least 35 minutes, for a safe level of cyanide in the tuber. Furthermore, since cassava peels contain high level of cyanide, its removal should be done in a well ventilated environment and disposal in pits or other places where human beings and animals may not be poisoned [38] [39].

\section{Acknowledgements}

We wish to thank the staff of Chemistry Department especially Mr. Pius Utange for the assistance rendered during the course of this work. We thank the farmers in the various local government areas for their cooperation and interest in the work. We appreciate the financial assistance of Center for Food Technology and Research (CEFTER), Benue State University, Makurdi-Nigeria, West Africa.

\section{References}

[1] Moller, B.L. and Conn, E.E. (1980) The Biosynthesis of Cyanogenic Glucosides in Higher Plants. Channeling of Intermediates in Dhurrin Biosynthesis by a Microsomal System from Sorghum bicolor (Linn) Moench. The Journal of Biological Chemistry, 255, 3049-3056.

[2] Poulton, J.E. (1990) Cyanogenesis in Plants. Plant Physiology, 94, 401-405. http://dx.doi.org/10.1104/pp.94.2.401

[3] Conn, E.E. (1991) Metabolism of Natural Products: Lesson Learned from Cyanogenic Glycosides. Planta Medica, 1, 57-68. http://dx.doi.org/10.1055/s-2006-960222

[4] Vetter, J. (2000) Plant Cyanogenic Glycosides. Toxicon, 38, 11-36. http://dx.doi.org/10.1016/S0041-0101(99)00128-2

[5] EPA (1990) Summary Review of Health Effects Associated with Hydrogen Cyanide. Health Issue Assessment Environmental Criteria and Assessment Office, Office of Health and Environment Assessment, Office of Research and Development, US Environmental Protection Agency Research Triangle Park, North Carolina.

[6] Allen, C. (1994) The Origin of Manihot esculenta Crantz (Euphorbiaceae). Genetic Resources and Crop Evolution, 41, 133-150. http://dx.doi.org/10.1007/BF00051630

[7] Olsen, K. and Schaal, B. (2001) Microsatellite Variation in Cassava (Manihot esculenta, Euphorbiaceae) and Its Wild Relatives: Further Evidence for a Southern Amazonian Origin of Domestication. American Journal of Botany, 88, 131-142. http://dx.doi.org/10.2307/2657133

[8] Food Standards Australia New Zealand (FSANZ) (2005) Cyanogenic Glycosides in Cassava and Bamboo Shoots: AHuman Health Risk Assessment. Technical Report Series No. 28. http://www.foodstandards.gov.au

[9] Nartey, F. (1978) Manihot esculenta in Africa: Utilization as Human Food and Animal Feed. Munksgaard, Copenhagen, 42-43.

[10] Cock, J. (1985) Cassava: New Potential for a Neglected Crop. Westview Press, Boulder Co., London, 191.

[11] Diasolua, D., Kuo, Y. and Lambein, F. (2003) Cassava Cyanogens and Free Amino Acids in Raw and Cooked Leaves. Food and Chemical Toxicology, 41, 1193-1197. http://dx.doi.org/10.1016/S0278-6915(03)00111-X

[12] Wheatley, C. and Chuzel, G. (1993) Cassava: The Nature of the Tuber and the Use as a Raw Material. In: Macrae, R., Robinson, R. and Sadler, M., Eds., Encyclopedia of Food Science, and Food Technology and Nutrition, Academic Press, San Diego, 734-743.

[13] Booth, R., De Bucle, T., Cardenas, O., Gomez, G. and Hervas, E. (1976) Changes in Quality of Cassava Roots during Storage. Journal of Food Technology, 11, 245-264. http://dx.doi.org/10.1111/j.1365-2621.1976.tb00721.x

[14] Ubwa, S.T., Adoga, S.O., Tyohemba, R.L. and Shambe, T. (2015) Quantitative Estimation of Hydrogen Cyanide in Fresh and Cooked Tuber Parenchyma (Pulp) of Three Cultivars of Sweet Cassava Cultivars Grown in Some Parts of Benue State, Nigeria. Food and Nutrition Sciences, 6, 836-844. http://dx.doi.org/10.4236/fns.2015.610087

[15] El-Sharkawy, M. (2004) Cassava Biology and Physiology. Plant Molecular Biology, 56, 481-501. http://dx.doi.org/10.1007/s11103-005-2270-7

[16] Chijindu, E.N. and Boateng, B. (2008) Effect of Nutritional Content of Processed Cassava Chips on Development of Prostephanus truncates (Horn). World Journal of Agricultural Sciences, 4, 404-408.

[17] Miya, E., Dedeca, S., Pereira, A., Shirose, I. and Angelucci, E. (1975) Sensory Chemical Evaluation of New Manioccultivars. Coletânea do Instituto de Tecnologia de Alimentos, 6, 257-275.

[18] Nweke, F., Ugwu, B., Dixon, A., Asadu, C. and Ajodo, O. (1999) Cassava Production in Nigeria: A Function of Farmer Access to Market and Improved Production and Processing Technologies. COSCA Working Paper No. 20, IITA, Ibadan. 
[19] Bokanga, M., Ekanayake, I.J., Dixon, A.G., Cyanogenic, O. and Porto, M.C.M. (1994) Genotype-Environment Interactions for Potential in Cassava. Acta Horticulturae, 375, 131-139.

[20] Charles, A., Chang, Y., Ko, W., Sriroth, K. and Huang, T. (2005) Influence of Amylopectin Structure and Amylose Content on the Gelling Properties of Five Cultivars of Cassava Starches. Journal of Agriculture and Food Chemistry, 53, 2717-2725. http://dx.doi.org/10.1021/jf048376+

[21] Bradbury, J., Egan, S. and Lynch, M. (1991) Analysis of Cyanide in Cassava Using Acid Hydrolysis of Cyanogenic Glucosides. Journal of the Science of Food and Agriculture, 55, 277-290. http://dx.doi.org/10.1002/jsfa.2740550213

[22] Food and Agricultural Organization (2007) June 2003 Cassava Market Assessment. www.fao.org/docrep/019/i3473e/i3473e.pdf

[23] White, W.L.B., Arias-Garzon, D.I., McMahon, J.M. and Sayre, R.T. (1998) Cyanogenesis in Cassava, the Role of Hydroxynitrile Lyase in Root Cyanide Production. Plant physiology, 116, 1219-1225. http://dx.doi.org/10.1104/pp.116.4.1219

[24] Cardoso, A.P., Mirione, E., Ernesto, M. and Massaza, F. (2005) Processing of Cassava Roots to Remove Cyanogens. Journal of Food Composition and Analysis, 18, 451-460. http://dx.doi.org/10.1016/j.jfca.2004.04.002

[25] Lambri, M., Fumi, M.D., Roda, A. and De Faveri, D.M. (2013) Improved Processing Methods to Reduce the Total Cyanide Content of Cassava Roots from Burundi. African Journal of Biotechnology, 12, 1285-1291.

[26] Surleva, A., Zaharia, M., Ion, L., Gradinaru, R.V., Drochioiu, G. and Mangalagiu, I. (2013) Ninhydrin-Based Spectrophotometric Assays of Trace Cyanide. Acta Chemica IASI, 21, 57-70. http://dx.doi.org/10.2478/achi-2013-0006

[27] Wheately, C.C., Orrego, J.I., Sanchez, T. and Granados, E., (1993) Quality Evaluation of Cassava Core Collection at CIAT. Proceedings of the First International Scientific Meeting of Cassava, Biotechnology Network, CIAT, Cali, 8-14 March 1993, 379-383. https://cgspace.cgiar.org/handle/10568/55695

[28] Tchacondo, T., Karou, S.D., Osseyi, E., Agban, A., Bawa, L.M., Atcha, A.R., Soumana, K., Assignon, K., Kpemoua, A. and De Souza, C. (2011) Effect of Harvest and Cook Processing on Cyanides Content of Cassava Cultivars and Cassava-Based Dough Consumed in Lomé, Togo. Advanced Journal of Food Science and Technology, 3, 398-402.

[29] Zheng, L. and Poulton, J.E. (1995) Temporal and Spatial Expression of Amygdalin Hydrolase and (R)-(+)-Mandelonitrile Lyase in Black Cherry Seeds. Plant Physiol, 109, 31-39. http://dx.doi.org/10.1104/pp.109.1.31

[30] White, W., McMahon, J. and Sayre, R.T. (1994) Regulation of Cyanogenesis in Cassava. Acta Horticulturae, 375, 69-78. http://dx.doi.org/10.17660/actahortic.1994.375.4

[31] Cooke, R.D. (1978) An Enzymatic Assay for the Total Cyanide Content of Cassava (Manihot esculenta Crantz). Journal of the Science of Food and Agriculture, 29, 345-352. http://dx.doi.org/10.1002/jsfa.2740290408

[32] Fomunyan, R.T., Adegbola, A.A. and Oke, O.L. (1985) The Stability of Cyanohydrins. Food Chemistry, 17, $221-225$. http://dx.doi.org/10.1016/0308-8146(85)90072-X

[33] Ma, J. and Dasgupta, P.K. (2010) Recent Developments in Cyanide Detection: A Review. Analytica Chimica Acta, 673, 117-125. http://dx.doi.org/10.1016/j.aca.2010.05.042

[34] Gernah, D.I., Ega, B.M. and Umoh, U.E. (2012) Effect of Boiling Time on the Quality of Zogale: A Snack Food Produced from Peanut (Arachis hypogea) Cake and Boiled Moringa oleifera Leave. Africa Journal of Food Science, 10, 287-293.

[35] White, W.L.B., Arias-Garzon, D.I., McMahon, J.M. and Sayre, R.T. (1998) Cyanogenesis in Cassava: The Role of Hydroxynitrile Lyase in Root Cyanide Production. Plant Physiology, 116, 1219-25. http://dx.doi.org/10.1104/pp.116.4.1219

[36] Nambiscan, B. and Sundarsan, S. (1985) Effect of Processing on the Cyanogenic Glucoside Content of Cassava. Journal of the Science of Food and Agriculture, 36, 1197-1203. http://dx.doi.org/10.1002/jsfa.2740361126

[37] Bourdoux, P., Segherd, P., Mafuta, M., Vanderpas, R.M., Delanga, F. and Ermans, A.M. (1982) Cassava Products: HCN Content and Detoxification Process. In: Delange, F., Iteke, F.B. and Ermans, A.M., Eds., Nutritional Factors Involved in the Goitrogenic Action of Cassava, IDRC, Ottawa, 51-75.

[38] Makene, W. and Wilson, J. (1972) Biochemical Studies in Tanzanian Patients with Ataxic Tropical Neuropathy. Journal of Neurology Neurosurgery Psychiatry, 35, 31-33. http://dx.doi.org/10.1136/jnnp.35.1.31

[39] Towill, L.E., Drury, J.S. Whitfield, B.L. Lewis, E.B. Galyan, E.L. and Hammons, A.S. (1978) Reviews of the Environmental Effects of Pollutants: V. Cyanide. EPA-600/1-78-027, US Environmental Protection Agency, Cincinnati. 